fraction appears to be strongly associated with the polyisoprenoid particles.

'Bottom fraction' solids contain RNA particles which are mainly associated with readily sedimentable material and which are liberated therefrom by treatment with deoxycholate. The free particles have the characteristics of ribosomal bodies in that they contain $25-30 \%$ of nucleic acid, dissociate into sub-units in the absence of bivalent cations and have the typical negatively-stained fenestrated appearance in phosphotungstic acid. The probable helical substructure of these RNA particles receives confirmation from the observation that on heating their aqueous preparations the extinction maximum in the ultraviolet region increases by an amount which is attributable to a breakdown of a $40 \%$ helical organization of such molecules (Hall \& Doty, 1959). This value is similar to that found by these authors and by Schlessinger (1960) for ribosomal particles in Escherichia coli. The presence of $60 \mathrm{~s}$ and $80 \mathrm{~s}$ particles has been detected in $E$. coli by Bolton, Hayer \& Ritter (1958) and the presence of $40 \mathrm{~s}, 60 \mathrm{~s}$ and $74 \mathrm{~s}$ particles in pea seedlings has been shown (Ts'O, Bonner \& Vinograd, 1956). The present results on Hevea are in conformity with such work.

\section{SUMMARY}

1. The isolation from Hevea latex of ribosomal particles containing $25 \%$ of RNA and their nucleotide analysis is described.
2. Such particles are reversibly aggregated in the presence of $\mathrm{Mg}^{2+}$ ions to a large aggregate with a sedimentation coefficient of $94 \mathrm{~s}$.

3. These ribosomes, on treatment with detergent, liberate cis-polyisoprene ultramicro-particles into the supernatant on centrifuging.

4. These polyisoprenoid particles contain polynucleotide material.

5. 'Normal' polyisoprene particles, obtained in the low-density 'cream' layer on centrifuging fresh latex, also contain polynucleotide to a similar degree, after exhaustive washing procedures.

Thanks are due to Dr Dickenson for the electronmicroscope preparations, to Mr G. Higgins for infraredspectra data and to Mrs I. C. Barnes for much of the experimental assistance.

\section{REFERENCES}

Bolton, E. T., Hayer, B. H. \& Ritter, D. B. (1958). lst Symp. biophys. Soc., Cambridge, Mass. London: Pergamon Press Ltd.

Cockbain, E. G. \& McMullen, A. I. (1951). Trans. Faraday Soc. 47, 322.

Cunneen, J. I., Higgins, G. \& Watson, W. F. (1959). J. Polym. Sci. 40, 1.

Dunn, D. B. (1959). Biochim. biophys. Acta, 34, 286.

Hall, B. J. \& Doty, P. (1959). J. molec. Biol. 1, 111.

Huxley, H. E. \& Zubay, G. (1960). J. molec. Biol. 2, 10. McMullen, A. I. (1959). Biochem. J. 72, 545.

Schlessinger, D. (1960). J. molec. Biol. 2, 92.

Ts'O, P. O. P. Bonner, J. \& Vinograd, J. (1956). J. biophys. biochem. Cytol. 2, 451.

\title{
Some Properties of a Kidney Adenosine Triphosphatase Relevant to Active Cation Transport
}

\author{
BY K. P. WHEELER AND R. WHITTAM \\ Department of Biochemistry, University of Oxford
}

(Received 18 June 1962)

It is well known that the active transport of ions across cell membranes depends on a supply of energy from cell metabolism, which may be aerobic or anaerobic. Since the only features common to both respiration and glycolysis are the synthesis of ATP from ADP and the oxidation and reduction of NAD, it has been widely inferred that the linkage of active transport to metabolism is through ATP, which is hydrolysed as ions are moved against concentration gradients. The possibility still exists, however, that a reversible oxido-reduction reaction, perhaps coupled to a reaction involving the fission of ATP, might be concerned in active transport. Evidence suggesting that the activetransport mechanism might have the effect of an enzyme which hydrolyses ATP was provided by the discovery in crab nerve (Skou, 1957), in various preparations from brain (Hess \& Pope, 1957; Järnefelt, 1961; Deul \& McIlwain, 1961; Aldridge, 1962) and in fragmented human-erythrocyte membranes (Post, Merritt, Kinsolving \& Albright, 1960; Dunham \& Glynn, 1961) of adenosine triphosphatases which are activated by $\mathrm{Na}^{+}$and $\mathrm{K}^{+}$ ions. This concept was supported by the demonstration of the inhibition of adenosine-triphosphatase activity by cardiac glycosides, such as 
ouabain (Skou, 1960; Post et al. 1960; Dunham \& Glynn, 1961), which are potent inhibitors of active cation transport (see Whittam, 1961a). Moreover, the comprehensive investigations of Bonting, Simon \& Hawkins (1961) have shown, not only that adenosine triphosphatases which are stimulated by $\mathrm{Na}^{+}$and $\mathrm{K}^{+}$ions are present in 29 out of 36 tissues of the cat, but also that the enzymic activities found in nervous tissue and in tissues concerned with secretion are higher than those in other tissues. Consistent with this finding is the correlation which exists between the adenosine-triphosphatase activity and the degree of potassium transport in sheep erythrocytes with either a low or high potassium content (Tosteson, Moulton \& Blaustein, 1960).

Because of the high rates of active cation transport and respiration in kidney-cortex slices (Mudge, 1951; Whittam \& Davies, 1954), we have made a detailed investigation of a kidney-cortex adenosine triphosphatase. Neville's (1960) isolation of cell membranes from the nuclear fraction of liver homogenates led us to study this fraction of a kidney-cortex homogenate. The main findings are that ATP hydrolysis may be stimulated when $\mathrm{Na}^{+}$and $\mathrm{K}^{+}$ions are present together and that such stimulation is counteracted by ouabain. The nature of the activation by these ions is different insofar as, in the presence of $\mathrm{K}^{+}$ions, the addition of $\mathrm{Na}^{+}$ ions always stimulates, whatever its concentration; whereas, in the presence of $\mathrm{Na}^{+}$ions, the gradual addition of $\mathrm{K}^{+}$ions first stimulates, giving a maximum of activity, and then causes a progressive fall to the level found in the absence of $\mathrm{K}^{+}$ions.

A preliminary report of some of these results has been published (Whittam \& Wheeler, 1961).

\section{METHODS}

Materials. All solutions were made in glass-distilled water. Ouabain (strophanthin-G), imidazole, choline chloride and trichloroacetic acid were Laboratory Reagent products of British Drug Houses Ltd. Bovine plasma albumin (fraction V) was obtained from the Armour Pharmaceutical Co. Ltd. and tris (Sigma 7-9) from the Sigma Chemical Co., St Louis, Mo., U.S.A. The disodium salt of ATP, supplied by the Sigma Chemical Co., was used in most experiments, although the salt produced by Boehringer und Soehne G.m.b.H., Mannheim, Germany, was used in a few. Solutions of ATP were buffered to the required $\mathrm{pH}$ with saturated tris solution and kept at $0-4^{\circ}$. All other compounds used were AnalaR reagents (British Drug Houses Ltd.).

ATP solutions containing very little sodium were prepared by treating the sodium salt of ATP as follows (modified from Järnefelt, 1961). About $5 \mathrm{~g}$. of Dowex 50 ion-exchange resin $\left(\mathrm{H}^{+}\right.$form) was suspended in $15 \mathrm{ml}$. of ice-cold water and $1 \mathrm{~g}$. of the sodium salt of ATP was added.
The mixture was shaken for $15 \mathrm{~min}$. in a bath containing ice and water and then rapidly filtered through sintered glass, the filtrate being collected in a chilled tube containing about $0.5 \mathrm{ml}$. of saturated tris solution. After the resin had been washed three times with $2 \mathrm{ml}$. of cold water, the filtrate and washings were adjusted to $\mathrm{pH} 8.0$ with ice-cold saturated tris solution. The concentration of the resulting tris-ATP was determined by ultraviolet-absorption measurements at $259 \mathrm{~m} \mu$ (Bock, Nan-Sing Ling, Morell \& Lipton, 1956) and the $\mathrm{Na}^{+}$ion concentration by flame photometry (Amoore, Parsons \& Werkheiser, 1958). About $95 \%$ of the purine moiety was recovered, and paperchromatographic analysis according to Krebs \& Hems (1953) showed that the ATP had not been hydrolysed during the conversion of the sodium into the tris salt. The sodium concentration was less than $11 \mathrm{~mm}$ in a stock solution of 60 mM-tris-ATP.

Preparation of tissue suspensions. Adult rabbits were stunned by a blow on the neck, bled from the throat, and the kidneys removed immediately. The medulla was cut away and 2-4 g. of cortex was homogenized in about $15 \mathrm{ml}$. of ice-cold $0.3 \mathrm{M}$-sucrose in a chilled glass homogenizer (clearance about $0.13 \mathrm{~mm}$.; $700 \mathrm{rev} . / \mathrm{min}$.), with one complete stroke of the pestle. The tissue suspension was adjusted to $10 \%(\mathrm{w} / \mathrm{v})$ by adding $0.3 \mathrm{M}$-sucrose and the homogenization continued with five up-and-down strokes of the pestle through $15 \mathrm{ml}$. portions of the suspension. The homogenate was squeezed through a double layer of muslin and then centrifuged at $800-850 \mathrm{~g}$ for $10 \mathrm{~min}$. at $0^{\circ}$ (MSE Refrigerator centrifuge; 6886 head; 2300-2400 rev./ min.). The supernatant was decanted, the lower layer of sedimented erythrocytes removed as completely as possible with a Pasteur pipette and the remainder of the sediment resuspended in cold $150 \mathrm{~mm}$-tris, previously buffered to the appropriate $\mathrm{pH}$ with $5 \mathrm{~N}-\mathrm{HCl}$. The suspension was centrifuged as above and the sediment resuspended in a suitable volume of the tris- $\mathrm{HCl}$ solution. This preparation was kept for up to $3 \mathrm{hr}$. at $0-4^{\circ}$ until it was used.

In experiments designed to investigate the effect of $\mathrm{pH}$, $0.3 \mathrm{M}$-sucrose solution was used in place of the tris-HCl solution throughout the procedure described above and the $\mathrm{pH}$ varied by adding suitable buffers to the incubation media.

Measurement of adenosine-triphosphatase activity. Tubes containing the appropriate media and tissue suspension were kept in ice-water until they were shaken in a water bath for $10 \mathrm{~min}$. at $37^{\circ}$ for thermal equilibration. The reaction was then initiated by the addition of ATP solution, the volume of which was normally one-twelfth of the total volume (usually $3 \mathrm{ml}$.), so that the cooling effect was insignificant. The tubes were covered with Parafilm (A. Gallenkamp and Co. Ltd., London) and well shaken immediately after the addition of ATP. The reaction was stopped, usually after 3 min., by adding ice-cold trichloroacetic acid solution $(35 \%, \mathrm{w} / \mathrm{v})$ to give a final concentration of $5 \%(w / v)$, and the tubes were returned to the ice-water. After the precipitated protein had been spun down, orthophosphate was estimated in samples from the supernatants by the method of Fiske \& Subbarow (1925), during which procedure there is no appreciable hydrolysis of ATP (Bartlett, 1959).

Tissue concentration. The dry weight of the tissue suspension, obtained by drying in an oven at about $105^{\circ}$ overnight, was used throughout as a convenient basis for 
comparing the rates of hydrolysis of ATP measured in different experiments. In several experiments the protein content of the suspensions was also estimated, by using the following slight modification of the biuret method (Robinson \& Hogden, 1940; Layne, 1957). The biuret reagent $(4 \mathrm{ml}$.) was added to $1 \mathrm{ml}$. of the tissue suspension and the mixture kept in a water bath at $20-25^{\circ}$ for $30 \mathrm{~min}$. with occasional shaking. The mixtures always remained slightly turbid, presumably because of insoluble lipid material, so this material was spun down before the measurement of the extinctions at $555 \mathrm{~m} \mu$. Standard solutions, prepared from crystalline bovine plasma albumin, reagent blanks and tris blanks were all treated in the same way. The protein content of the homogenates was expressed as its equivalent of albumin.

Paper chromatography. Samples of the supernatant solutions remaining after precipitation of the protein were analysed qualitatively for ATP, ADP and AMP by paper chromatography (Krebs \& Hems, 1953). The nucleotide products of the ATP hydrolysis occurring during various incubation periods and during incubations with different concentrations of tissue, in the presence and absence of ouabain, were investigated and correlated with the concentrations of orthophosphate found in the same samples.

\section{RESULTS}

\section{Measurement of the rate of hydrolysis of adenosine triphosphate}

Dependence on the dry weight of tissue and on the time of incubation. Preliminary experiments were designed to find suitable conditions, with respect to duration of incubation and concentration of tissue, for measuring the initial rates of liberation of orthophosphate from ATP. The amount of orthophosphate liberated was linear with the time of incubation up to $8 \mathrm{~min}$. (Fig. 1), when less than $12 \%$ of the terminal phosphate of ATP was hydrolysed. The rate of orthophosphate formation was also linear with respect to the concentration of tissue in the range $0.17-1.2 \mathrm{mg}$. dry wt./ml. of suspension, both in the presence and absence of ouabain, which merely decreased the rate by about $50 \%$ with each dry weight of tissue (Fig. 2). For all further experiments, the time of incubation was standardized at $3 \mathrm{~min}$., and the concentration of tissue was within the range $0.08-0.80 \mathrm{mg}$. dry wt. $/ \mathrm{ml}$. of suspension, corresponding to $0.02-0.35 \mathrm{mg}$. of protein $/ \mathrm{ml}$. of suspension.

Products of hydrolysis of adenosine triphosphate. The trichloroacetic acid extracts from the experiments illustrated in Figs. 1 and 2 were analysed for ATP, ADP and AMP by paper chromatography. Only ADP, besides ATP, could be detected on visual inspection of the chromatograms under ultraviolet light (Chromatolite lamp, Hanovia Ltd., Slough, Bucks.), and the amount of ADP increased as the duration of incubation was lengthened or as the concentration of tissue was raised. Similarly less ADP was produced when ouabain was added to

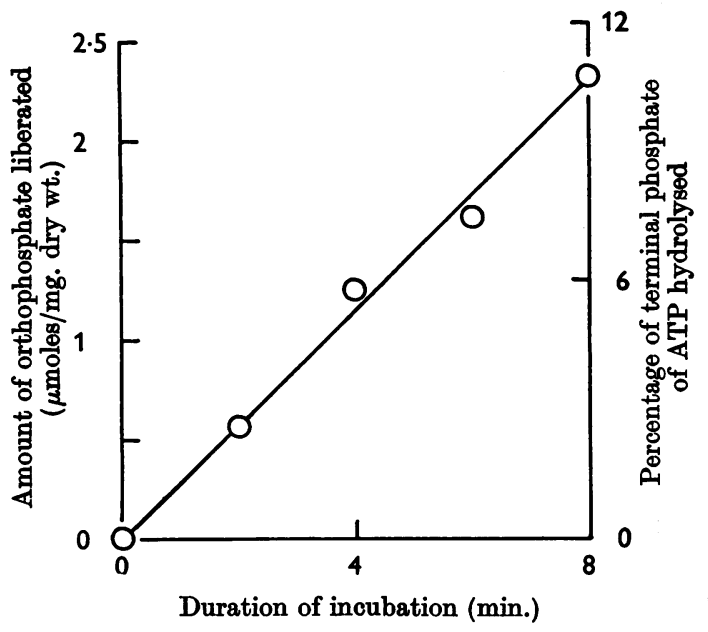

Fig. 1. Linearity with time of the hydrolysis of adenosine triphosphate by the nuclear fraction of a kidney-cortex homogenate. The amount of orthophosphate produced by hydrolysis of the terminal phosphate of ATP in the tissue suspension during various periods of incubation at $37^{\circ}$ was measured. Samples of suspension (final volume $3.0 \mathrm{ml}$.) contained (final concentrations) 3 mM-ATP (Sigma disodium salt, buffered to $\mathrm{pH} 8.0$ with tris), $3 \mathrm{~mm}-\mathrm{MgCl}_{2}$, $50 \mathrm{~mm}-\mathrm{KCl}, 50 \mathrm{~mm}-\mathrm{NaCl}, 40 \mathrm{~mm}-$ tris-HCl, pH $8 \cdot 0$, and $0 \cdot 14 \mathrm{mg}$. dry wt. of tissue $/ \mathrm{ml}$.

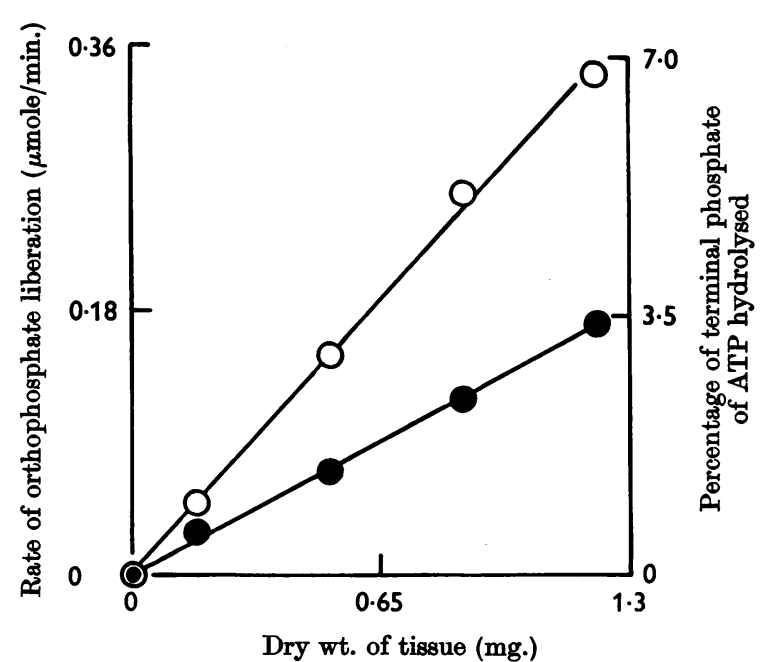

Fig. 2. Proportionality of the rate of adenosine triphosphate hydrolysis with the tissue concentration. The amounts of orthophosphate liberated were measured after incubation at $37^{\circ}$ for 2 or 5 min., according to the amount of tissue present, in media containing (final concentrations) $50 \mathrm{~mm}-\mathrm{KCl}, 50 \mathrm{~mm}-\mathrm{NaCl}, 5 \mathrm{~mm}-\mathrm{MgCl}_{2}, 35 \mathrm{~mm}$-tris-HCl, $\mathrm{pH} 8 \cdot 0$, and 5 mM-ATP (Sigma disodium salt, buffered to pH 8.0 with tris). $O$, Without ouabain; $O$, with $0.33 \mathrm{~mm}$ ouabain. 
inhibit the reaction. When the period of incubation was increased to 10-15 min., however, AMP was also detected in the trichloroacetic acid extracts, indicating the breakdown of ADP. The standard conditions given above therefore gave a means of measuring the initial rate of the reaction:

$$
\mathrm{ATP} \rightarrow \mathrm{ADP} \text { + orthophosphate }
$$

and the rate of liberation of orthophosphate is referred to as the 'adenosine-triphosphatase activity'.

Accuracy of rate measurements. The accuracy of the measurements of the rates of hydrolysis of ATP in a single experiment was estimated by measuring six times the amounts of orthophosphate produced during incubations in the presence and absence of ouabain. The media contained sodium chloride (50 $\mathrm{mM})$, potassium chloride $(50 \mathrm{mM})$, magnesium chloride (5 mM), ATP (5 mM), tris-hydrochloric acid, $\mathrm{pH} 8.0$ ( $35 \mathrm{mM})$, and a tissue concentration of $0.54 \mathrm{mg}$. dry wt./ml. The mean rates \pm S.D. of orthophosphate liberation ( $\mu$ moles of orthophosphate/mg. dry wt./hr.) were $16 \cdot 7 \pm 1 \cdot 0$ (range 14.9
17.2) without ouabain, and $7 \cdot 8 \pm 0 \cdot 5$ (range $7 \cdot 5-8 \cdot 7$ ) with ouabain, indicating an experimental error of about $6 \%$. The highly significant difference between these means \pm S.E. was $8 \cdot 9 \pm 0 \cdot 5$.

\section{General sensitivity to cations and to ouabain of the hydrolysis of adenosine triphosphate}

Stimulation by maynesium, sodium and potassium ions. The influence of cations and ouabain on the rate of ATP hydrolysis is shown by the results in Table 1. The rate was insignificantly low in the absence of $\mathrm{Mg}^{2+}$ ions, whether or not $\mathrm{Na}^{+}$and $\mathrm{K}^{+}$ ions, separately or together, were also present (Expt. 1). The presence of 5 mM-magnesium chloride alone, however, increased the rate of orthophosphate liberation ( $\mu \mathrm{moles} / \mathrm{mg}$. dry wt./hr.) from 0.4 to 9.9 . No further increase was found in the presence of either 50 mM-sodium chloride or 50 mM-potassium chloride as well as the magnesium chloride, but when $\mathrm{Na}^{+}$and $\mathrm{K}^{+}$ions were added together the rate of ATP hydrolysis rose to $14 \cdot 7$.

Inhibition by ouabain. Ouabain had no effect on the adenosine-triphosphatase activity in the

Table 1. Sensitivity of adenosine triphosphate hydrolysis to magnesium, sodium and potassium ions, and to ouabain

Samples of the suspension of the nuclear fraction from kidney-cortex homogenate, prepared as described in the Methods section, were incubated at $37^{\circ}$ in the presence and absence of $\mathrm{Na}^{+}$ions, $\mathrm{K}^{+}$ions, $\mathrm{Mg}^{2+}$ ions and ouabain. The final concentration of ouabain was $\mathbf{0 . 3 3} \mathrm{mm}$. In Expt. 1, ATP was added as the tris salt (obtained by ion-exchange from the disodium salt as described in the Methods section), giving a final concentration of $5 \mathrm{mM}$, in media buffered with $25 \mathrm{~mm}$-tris-HCl, $\mathrm{pH} \mathrm{8.0.} \mathrm{The} \mathrm{residual} \mathrm{Na}+$ ions in the ATP solution have been included with the $\mathrm{NaCl}$ concentration. The final volume was $3.0 \mathrm{ml}$., and the dry wt. of tissue $0.63 \mathrm{mg} . / \mathrm{ml}$. In Expt. 2 , the media contained $15 \mathrm{~mm}$-tris-HCl, pH 8.0, choline chloride instead of sucrose, and the disodium salt of ATP (Sigma), previously buffered to pH 8.0 with tris. The dry wt. of tissue was 0.72-0.92 mg./ml. The reaction was stopped after $3 \mathrm{~min}$. by adding $0.5 \mathrm{ml}$. of $35 \%(\mathrm{w} / \mathrm{v})$ ice-cold trichloroacetic acid, and the precipitated protein spun down. Samples from the supernatent were analysed in duplicate for orthophosphate by the method of Fiske \& Subbarow (1925), and the rates of orthophosphate liberation calculated. The values in parentheses refer to the number of observations, and the effects of additions of $\mathrm{NaCl}, \mathrm{KCl}, \mathrm{MgCl}_{2}$ and ouabain were found by difference.

Rate of orthophosphate liberation ( $\mu \mathrm{moles} / \mathrm{mg}$. dry wt./hr.)

\begin{tabular}{|c|c|c|c|c|c|c|c|c|c|c|c|c|}
\hline \multirow[b]{2}{*}{$\begin{array}{c}\text { Expt. } \\
\text { no. }\end{array}$} & \multicolumn{5}{|c|}{ Concn. of solutes (mM) } & \multirow[b]{2}{*}{$\begin{array}{l}\text { Without } \\
\text { ouabain }\end{array}$} & \multirow[b]{2}{*}{$\begin{array}{c}\text { With } \\
\text { ouabain }\end{array}$} & \multirow[b]{2}{*}{$\begin{array}{c}\text { Inhibition } \\
\text { due to } \\
\text { ouabain }\end{array}$} & \multicolumn{2}{|c|}{$\mathrm{KCl}+\underbrace{\mathrm{NaCl}}$} & \multicolumn{2}{|c|}{$\mathrm{MgCl}_{2}$} \\
\hline & $\mathrm{MgCl}_{2}$ & $\mathrm{KCl}$ & $\mathrm{NaCl}$ & Sucrose & $\begin{array}{l}\text { Choline } \\
\text { chloride }\end{array}$ & & & & $\begin{array}{l}\text { Without } \\
\text { ouabain }\end{array}$ & $\begin{array}{c}\text { With } \\
\text { ouabain }\end{array}$ & $\begin{array}{l}\text { Without } \\
\text { ouabain }\end{array}$ & $\begin{array}{c}\text { With } \\
\text { ouabain }\end{array}$ \\
\hline 1 & $\begin{array}{l}\mathbf{0} \\
\mathbf{0} \\
\mathbf{0} \\
\mathbf{0} \\
\mathbf{5} \\
\mathbf{5} \\
\mathbf{5} \\
\mathbf{5}\end{array}$ & $\begin{array}{r}\mathbf{0} \\
\mathbf{0} \\
\mathbf{5 0} \\
\mathbf{5 0} \\
0 \\
0 \\
\mathbf{5 0} \\
\mathbf{5 0}\end{array}$ & $\begin{array}{r}1 \\
51 \\
1 \\
51 \\
1 \\
51 \\
1 \\
51\end{array}$ & $\begin{array}{r}215 \\
115 \\
115 \\
15 \\
200 \\
100 \\
100 \\
0\end{array}$ & $\begin{array}{l}\mathbf{0} \\
\mathbf{0} \\
\mathbf{0} \\
\mathbf{0} \\
\mathbf{0} \\
\mathbf{0} \\
\mathbf{0} \\
\mathbf{0}\end{array}$ & $\begin{array}{r}0.4 \\
1 \cdot 1 \\
0.4 \\
0.6 \\
9 \cdot 9 \\
8 \cdot 3 \\
8 \cdot 3 \\
14 \cdot 7\end{array}$ & $\begin{array}{l}0.4 \\
1 \cdot 1 \\
0.0 \\
0 \cdot 6 \\
7 \cdot 6 \\
7 \cdot 4 \\
8 \cdot 1 \\
8.3\end{array}$ & $\begin{array}{l}0 \\
0 \\
0 \cdot 4 \\
0 \\
2 \cdot 3 \\
0 \cdot 9 \\
0 \cdot 2 \\
6 \cdot 4\end{array}$ & $\begin{array}{l}\bar{Z} \\
\overline{0} \\
\overline{-} \\
\overline{-} \\
+4 \cdot 8\end{array}$ & $\begin{array}{l}\overline{-} \\
\overline{-} \\
+0.2 \\
\bar{z} \\
\overline{+0.7}\end{array}$ & $\begin{array}{r}- \\
- \\
\overline{-} \\
+9.5 \\
+7.2 \\
+7.9 \\
+14.1\end{array}$ & $\begin{array}{l}\bar{Z} \\
\bar{z} \\
\overline{+7 \cdot 2} \\
+6 \cdot 3 \\
+8 \cdot 1 \\
+7 \cdot 1\end{array}$ \\
\hline 2 & $\begin{array}{l}\mathbf{5} \\
\mathbf{5} \\
\mathbf{5} \\
\mathbf{5} \\
\mathbf{5} \\
\mathbf{5} \\
\mathbf{5} \\
\mathbf{5}\end{array}$ & $\begin{array}{l}\mathbf{0} \\
\mathbf{0} \\
\mathbf{0} \\
\mathbf{0} \\
\mathbf{5 0} \\
\mathbf{5 0} \\
\mathbf{5 0} \\
\mathbf{5 0}\end{array}$ & $\begin{array}{l}10 \\
30 \\
50 \\
70 \\
10 \\
30 \\
50 \\
70\end{array}$ & $\begin{array}{l}0 \\
0 \\
0 \\
0 \\
0 \\
0 \\
0 \\
0\end{array}$ & $\begin{array}{r}120 \\
100 \\
80 \\
60 \\
70 \\
50 \\
30 \\
10\end{array}$ & $\begin{array}{l}11.8(3) \\
11.1(2) \\
10.8(3) \\
12.4(2) \\
12.1(3) \\
14.9(3) \\
16.6(3) \\
16.8(3)\end{array}$ & $\begin{array}{l}11.0(2) \\
10.6(2) \\
10.6(2) \\
11.3(2) \\
10.6(3) \\
11.0(2) \\
10.5(2) \\
11.1(2)\end{array}$ & $\begin{array}{l}0.8 \\
0.5 \\
0.2 \\
1 \cdot 1 \\
1 \cdot 2 \\
\mathbf{3} \cdot 9 \\
\mathbf{6} \cdot 1 \\
\mathbf{5} \cdot \mathbf{7}\end{array}$ & $\begin{array}{l}- \\
\bar{Z} \\
\overline{+} \\
+0.3 \\
+3.8 \\
+5.8 \\
+4.4\end{array}$ & $\begin{array}{l}I \\
\bar{Z} \\
\overline{-0.4} \\
+0.4 \\
-0.1 \\
-0.3\end{array}$ & $\begin{array}{l}= \\
= \\
z \\
=\end{array}$ & $\begin{array}{l}- \\
= \\
z \\
z \\
-\end{array}$ \\
\hline
\end{tabular}


absence of $\mathrm{Mg}^{2+}$ ions, and only a negligible effect in the presence of $\mathbf{M g}^{2+}$ ions alone, $\mathbf{M g}^{2+}$ plus $\mathrm{Na}^{+}$ ions, or $\mathrm{Mg}^{2+}$ plus $\mathrm{K}^{+}$ions. When all three cations were added, however, ouabain lowered the rate of ATP hydrolysis by about $40 \%$, i.e. to that observed with $\mathrm{Mg}^{2+}$ ions alone.

The results of Expt. 2 in Table 1 give more details about the activation by $\mathrm{Na}^{+}$plus $\mathrm{K}^{+}$ions and the inhibition by ouabain. There was no significant change in the rate of ATP hydrolysis when $10,30,50$ or 70 mM-sodium chloride was present with $\mathrm{Mg}^{2+}$ ions, and no significant inhibition by ouabain. When 50 mM-potassium chloride was also present, however, the adenosine-triphosphatase activity increased at each concentration of $\mathrm{Na}^{+}$ions if ouabain was absent, but no change occurred if ouabain was present. Further, the increase observed when both $\mathrm{Na}^{+}$and $\mathrm{K}^{+}$ions were added was proportional to the $\mathrm{Na}^{+}$ion concentration within the range $10-50 \mathrm{mM}$, but no further rise occurred when the $\mathrm{Na}^{+}$ion concentration was raised to $70 \mathrm{~mm}$.

Thus the general sensitivity of the adenosine triphosphatase to the cations considered is shown by the dependence on $\mathrm{Mg}^{2+}$ ions for significant activity and by the stimulation of the activity when $\mathrm{Na}^{+}$and $\mathrm{K}^{+}$ions are also added together. Ouabain prevents the stimulation by $\mathrm{Na}^{+}$and $\mathrm{K}^{+}$ ions, but has no effect on the $\mathbf{M g}^{2+}$ ion-dependent hydrolysis.

\section{Interdependence of the concentrations of magnesium ions and adenosine triphosphate}

The proportions of $\mathrm{Mg}^{2+}$ ions and ATP required for maximal activity of liver-mitochondrial adenosine triphosphatases vary with $\mathrm{pH}$ (Kielley \& Kielley, 1953). At $\mathrm{pH}$ values in the region $6 \cdot 9-7 \cdot 6$, however, maximal activity of adenosine triphosphatase in liver homogenate (Swanson, 1951), liver mitochondria (Kielley \& Kielley, 1953), muscle myofibrils (Perry \& Grey, 1956), erythrocytes (Dunham \& Glynn, 1961), brain microsomes (Deul \& McIlwain, 1961) and submicroscopic particles from crab nerve (Skou, 1960), occurs when $\mathrm{Mg}^{2+}$ ions and ATP are present in equimolar concentrations, although Skou (1960) found that twice as much $\mathrm{Mg}^{2+}$ ion as ATP was necessary for maximal activity of the $\mathrm{Mg}^{2+}$ ion-plus- $\mathrm{Na}^{+}$ion-plus- $\mathrm{K}^{+}$iondependent adenosine triphosphatase from crab nerve. Investigation of the effect of the $\mathrm{Mg}^{2+}$ ion concentration on ATP hydrolysis at $\mathrm{pH} 8.0$ with the present preparation gave less clear-cut results. The rate of ATP hydrolysis did vary according to the $\left[\mathrm{Mg}^{2+}\right]$ : [ATP] ratio in the media (Fig. 3), but no sharp peak of activity was observed. Instead, rather broad maxima resulted when the $\left[\mathrm{Mg}^{2+}\right]$ : [ATP] ratio lay between about 0.5 and 1.5 ; but an increase to 5 caused a $50 \%$ fall in the rate from the maximum in the absence of ouabain, and a $30 \%$ fall when ouabain was present. In all other experiments magnesium chloride and ATP were therefore added in equimolar concentrations.

\section{Effect of $\mathrm{pH}$ on the adenosine- triphosphatase activity}

The influence of $\mathrm{pH}$ on the adenosine-triphosphatase activity was investigated by measuring the rates of ATP hydrolysis over the $\mathrm{pH}$ range 6.5-9.1. Each suspension was buffered with $50 \mathrm{~mm}$-trishydrochloric acid and $50 \mathrm{~mm}$-imidazole-hydrochloric acid at the desired $\mathrm{pH}$, which was measured on duplicate samples of each medium. Fig. 4 shows typical $\mathrm{pH}$-activity curves obtained from such experiments. The adenosine-triphosphatase activity measured in the presence of $\mathrm{Mg}^{2+}, \mathrm{Na}^{+}$and $\mathrm{K}^{+}$ions always showed a peak in the pH range $7 \cdot 8-8 \cdot 1$, although the exact shape of the curve varied from experiment to experiment. When ouabain was added, however, there was only a relatively small increase in rate in the $\mathrm{pH}$ range $\mathbf{7 \cdot 8 - 8 \cdot 1}$, indicating that the $\mathrm{Na}^{+}$ion-plus- $\mathrm{K}^{+}$ion-dependent part of the enzymic activity was mainly responsible for the $\mathrm{pH}$

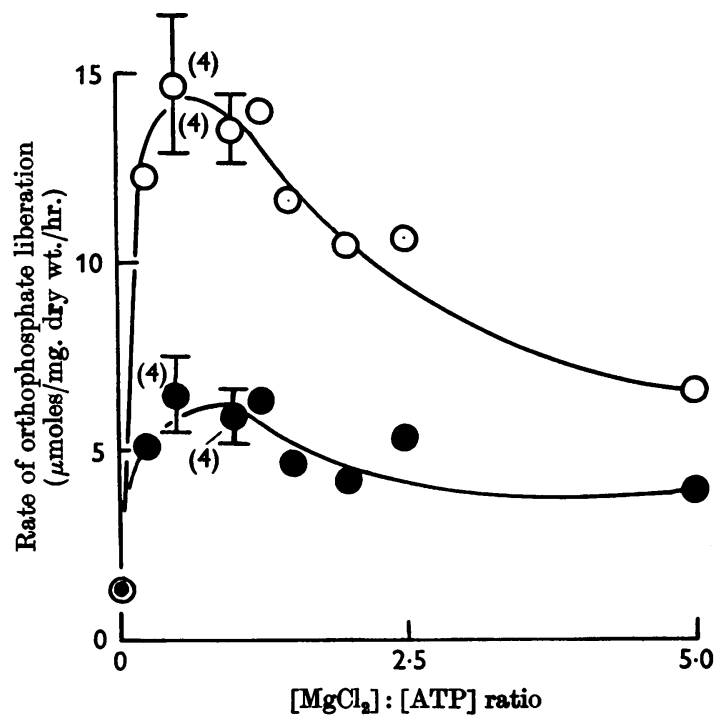

Fig. 3. Stimulation and inhibition of adenosine-triphosphatase activity by $\mathrm{MgCl}_{2}$. Samples (3.0 ml.) of the tissue suspension were incubated for $3 \mathrm{~min}$. at $37^{\circ}$, with tissue dry weights of $0.24-0.39 \mathrm{mg} . / \mathrm{ml}$. (three experiments). The rates of orthophosphate liberation were measured from $2,4,5$ and $8 \mathrm{~mm}$-ATP (Sigma disodium salt, buffered to $\mathrm{pH} 8.0$ with tris), and the concentration of $\mathrm{MgCl}_{2}$ was varied from 0 to $10 \mathrm{~mm}$ in each case. The samples contained (final concentrations) $20 \mathrm{~mm}-\mathrm{KCl}, 110 \mathrm{~mm}-\mathrm{Na}^{+}, 15 \mathrm{~mm}$-tris-HCl, $\mathrm{pH} \mathrm{8.0,} \mathrm{and} \mathrm{0-30} \mathrm{mM-sucrose} \mathrm{to} \mathrm{maintain} \mathrm{iso-osmolarity.}$ Mean values are given, the s.E.M. being indicated where possible. $O$, Without ouabain; 0 , with 0.33 mm-ouabain. 
optimum observed in the absence of ouabain. The $\mathrm{pH}$-activity curve for the $\mathrm{Na}^{+}$ion-plus- $\mathrm{K}^{+}$iondependent activity shown in Fig. 4 was obtained by plotting the differences in the rates of ATP hydrolysis measured in the presence and absence of ouabain, thus illustrating the sensitivity of this part of the adenosine-triphosphatase activity to $\mathrm{pH}$.

Effect of adenosine triphosphate concentration on the rate of hydrolysis and on the nature of the inhibition by ouabain

Fig. 5 shows the inhibition produced by different concentrations of ouabain on the rate of ATP hydrolysis. At least 80-100 mM-ouabain was required for maximal inhibition, and about $20 \mathrm{~mm}$ for half-maximal inhibition.

The dependence of the rate of ATP hydrolysis on the ATP concentration, in the presence and absence of ouabain, was examined to determine the nature of the inhibition by ouabain, and to obtain a value for the $K_{m}$ of ATP. The rate of orthophosphate liberation increased with increasing concentrations of ATP up to about 1.5 mM-ATP (Fig. 6). Three experiments gave values of the $K_{m}$ in the

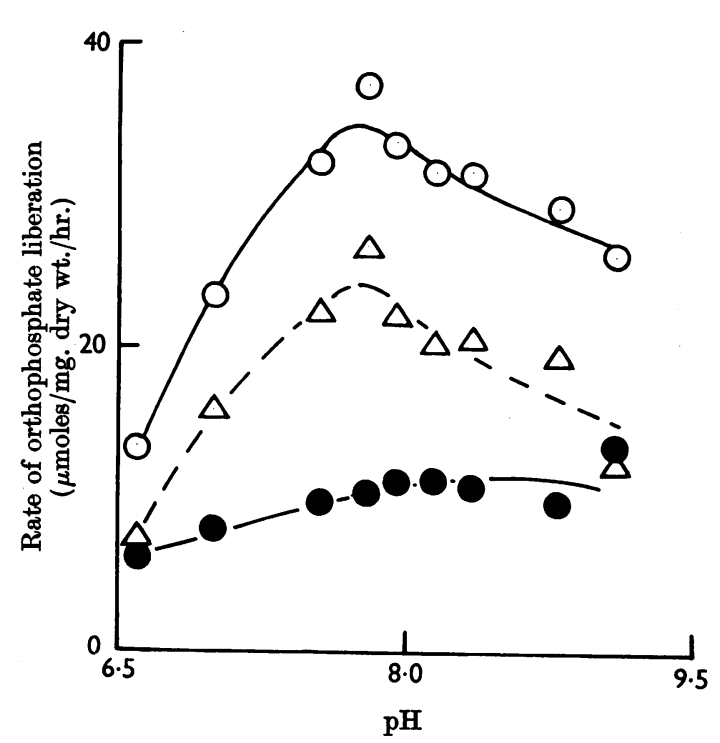

Fig. 4. Effect of $\mathrm{pH}$ on adenosine-triphosphatase activity. Each incubation mixture was adjusted to the appropriate $\mathrm{pH}$ with $50 \mathrm{~mm}$-tris-HCl and $50 \mathrm{~mm}$-imidazole-HCl. Samples of these suspensions contained (final concentrations) $20 \mathrm{~mm}-\mathrm{KCl}, 100 \mathrm{~mm}-\mathrm{NaCl}, 4 \mathrm{~mm}-\mathrm{MgCl}_{2}$, $4 \mathrm{~mm}-\mathrm{ATP}$ (Sigma disodium salt, buffered to $\mathrm{pH} 8.0$ with tris) and $0.15 \mathrm{mg}$. dry wt. of tissue $/ \mathrm{ml}$. The amount of orthophosphate liberated from the ATP during $3 \mathrm{~min}$. incubations at $37^{\circ}$ was determined, and the $\mathrm{pH}$ values were measured on duplicates of each sample. $O$, Without ouabain; $O$, with 0.33 mm-ouabain; $\triangle$, ouabain-sensitive activity. range 0.4-0.7 mM-ATP for the $\mathrm{Mg}^{2+}$ ion-plus$\mathrm{Na}^{+}$ion-plus- $\mathrm{K}^{+}$ion-dependent hydrolysis, and in the range $0 \cdot 6-1.4 \mathrm{~mm}$ for the ouabain-sensitive part. The inhibition by ouabain was not competitive with respect to ATP.

Dependence of adenosine-triphosphatase activity on the relative concentrations of sodium and potassium ions

Synergy of the stimulation. The results so far have indicated that, with the concentrations used, both $\mathrm{Na}^{+}$and $\mathrm{K}^{+}$ions are required together to stimulate the adenosine-triphosphatase activity. Thus the results in Table 1 show that ATP hydrolysis did not increase significantly when either $\mathrm{Na}^{+}(10-70 \mathrm{mM})$ or $\mathrm{K}^{+}(50 \mathrm{mM})$ ions were added alone, but that addition of the ions together always caused stimulation. The $\mathrm{Na}^{+}$ion concentration was never less than $10 \mathrm{~mm}$, however, and to check the possibility that 1-10 mM- $\mathrm{Na}^{+}$ion alone might stimulate, the rates of ATP hydrolysis were measured within this range of $\mathrm{Na}^{+}$ion concentrations. In the absence of $\mathrm{K}^{+}$ions, the rates of orthophosphate liberation ( $\mu$ moles/mg. dry wt./hr.) with 1, 2, 5 and $10 \mathrm{~mm}$ -

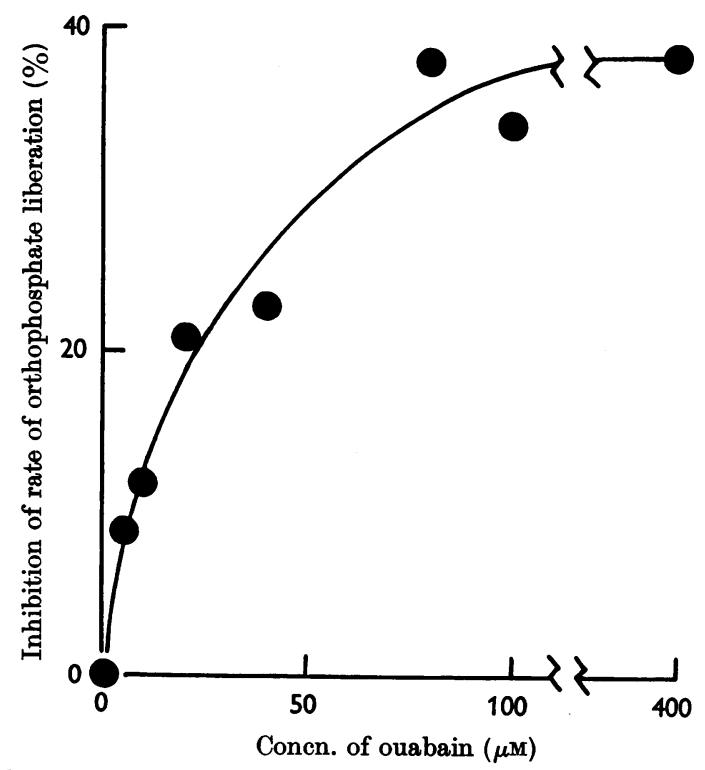

Fig. 5. Inhibition of adenosine-triphosphatase activity by various concentrations of ouabain. Various concentrations of ouabain were added to tissue suspensions containing (final concentrations) $20 \mathrm{~mm}-\mathrm{KCl}, 100 \mathrm{~mm}-\mathrm{NaCl}, 17.5 \mathrm{~mm}-$ tris-HCl, pH 8.0, 0.5 mM-ATP (Sigma disodium salt, buffered to $\mathrm{pH} 7.8$ with tris), $0.5 \mathrm{mM}^{-\mathrm{MgCl}_{2}}$ and $0.08 \mathrm{mg}$. dry wt. of tissue $/ \mathrm{ml}$. The amount of orthophosphate liberated was determined after incubating at $37^{\circ}$ for $3 \mathrm{~min}$. The graph shows the combined results from two experiments as the percentage fall in the rate of liberation of orthophosphate with the different ouabain concentrations. 
$\mathrm{Na}^{+}$ion were $12 \cdot 5,13 \cdot 8,13 \cdot 8$ and $14 \cdot 0$ respectively, which are not significantly different from one another. In contrast, when $1 \mathrm{~mm}-\mathrm{K}^{+}$ion was present together with $10 \mathrm{~mm}-\mathrm{Na}^{+}$ion, the rate rose to $19 \cdot 1$. Hence all observations indicate that the presence of both $\mathrm{Na}^{+}$and $\mathrm{K}^{+}$ions is required for stimulation of the adenosine triphosphatase.

The interdependence of $\mathrm{Na}^{+}$and $\mathrm{K}^{+}$ions in stimulating adenosine-triphosphatase activity may be investigated by maintaining the concentration of one ion constant while that of the other is varied, or by interchanging one ion for the other, keeping the sum of their concentrations constant. The former method was employed first, and either choline chloride or sucrose used to maintain iso-osmolarity; duplicate incubations, with sucrose in one and choline chloride in the other, gave similar results.

Inhibition by high concentrations of potassium ions. Fig. 7 shows the effect of increasing the $\mathrm{K}^{+}$ion concentration from 0 to $100 \mathrm{~mm}$ with constant $\mathrm{Na}^{+}$ ion concentrations of either 10 or $50 \mathrm{~mm}$. With $10 \mathrm{~mm}-\mathrm{Na}^{+}$ion the rate of orthophosphate liberation rose rapidly with increase in the $\mathrm{K}^{+}$ion concentration, reaching a peak at about $5 \mathrm{~mm}-\mathrm{K}^{+}$ion. Further increase in the $\mathrm{K}^{+}$ion concentration, however, caused a fall in rate such that the rates with

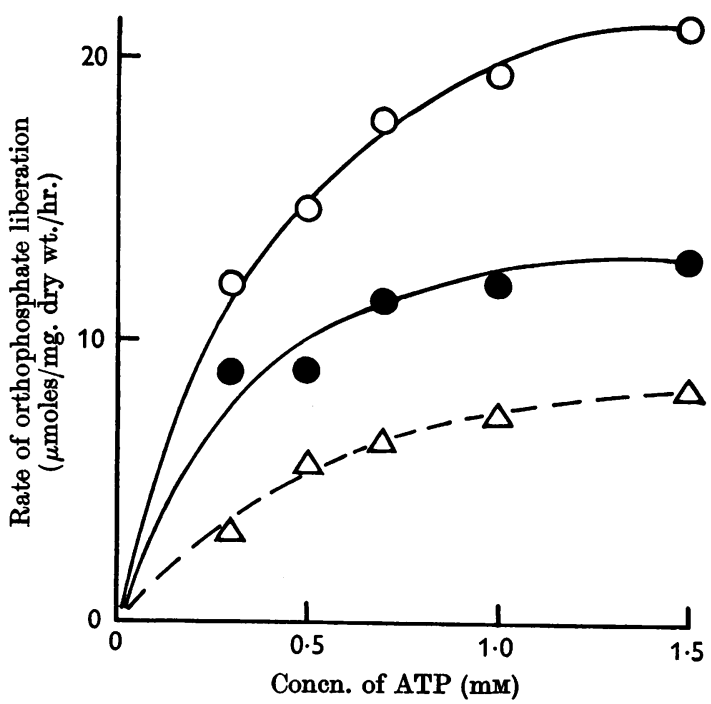

Fig. 6. Increase in adenosine-triphosphatase activity with increasing concentrations of adenosine triphosphate. Samples of tissue suspension containing (final concentrations) $100 \mathrm{~mm}-\mathrm{NaCl}, 20 \mathrm{~mm}-\mathrm{KCl}, 5 \mathrm{~mm}$-imidazole-HCl, $\mathrm{pH} 7 \cdot 8$, and $17.5 \mathrm{~mm}$-tris- $\mathrm{HCl}, \mathrm{pH} 7 \cdot 8$, were incubated at $37^{\circ}$ for 3 min. with $\mathrm{ATP}$ and $\mathrm{MgCl}_{2}$ in equimolar concentrations. The ATP solution was prepared from the Sigma disodium salt, and was buffered to $\mathrm{pH} 7.8$ with tris. The concentration of tissue was $0.08 \mathrm{mg}$. dry wt./ml. $O$, Without ouabain; 0 , with $0.1 \mathrm{mm-ouabain;} \triangle$, ouabainsensitive activity.
0 and $50 \mathrm{~mm}-\mathrm{K}^{+}$ion were about the same. A similar effect was found with $\mathrm{K}^{+}$ions in the presence of $50 \mathrm{mM}-\mathrm{Na}^{+}$ion, but in this case the peak of activity occurred with about $20 \mathrm{~mm}-\mathrm{K}^{+}$ion and the subsequent fall in rate at higher $\mathrm{K}^{+}$ion concentrations was more gradual. The stimulating effect of $\mathrm{K}^{+}$ions in the presence of a constant $\mathrm{Na}^{+}$ion concentration therefore depends on its concentration. In contrast, raising the concentration of $\mathrm{Na}^{+}$ion from 10 to $50 \mathrm{~mm}$, with a constant $\mathrm{K}^{+}$ion concentration of $50 \mathrm{~mm}$, increased the rate of ATP hydrolysis by about $37 \%$ (Table 1, Expt. 2), and no further change in the rate occurred when the $\mathrm{Na}^{+}$ ion concentration was increased to $70 \mathrm{~mm}$. Hence two conclusions emerge from these observations: first, the rate of ATP hydrolysis increases to a maximum and then falls as the $K^{+}$ion concentration is progressively raised with a constant $\mathrm{Na}^{+}$ion concentration; secondly, the rate of ATP hydrolysis simply increases to a maximum as the $\mathrm{Na}^{+}$ion concentration is raised with a constant $\mathrm{K}^{+}$ion concentration.

Importance of the ratio of the concentrations of sodium and potassium ions. To test whether the rate of ATP hydrolysis might depend on the ratio of the concentrations of $\mathrm{Na}^{+}$and $\mathrm{K}^{+}$ions rather than on the individual concentrations, adenosine-

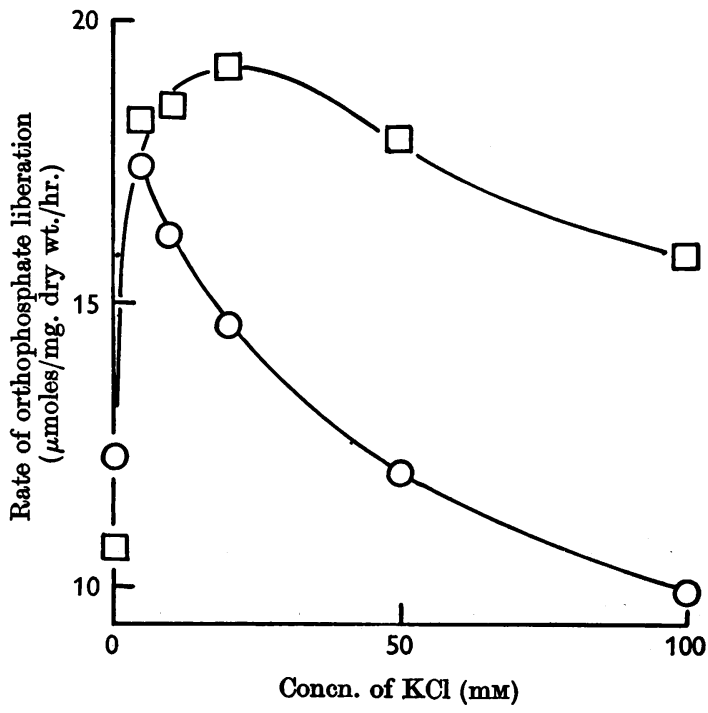

Fig. 7. Dependence of adenosine-triphosphatase activity on the $\mathrm{K}^{+}$ion concentration with constant $\mathrm{Na}^{+}$ion concentrations. The rate of orthophosphate liberation from ATP was measured at $37^{\circ}$ in samples of tissue suspension containing (final concentrations) $5 \mathrm{~mm}-\mathrm{MgCl}_{2}, 5 \mathrm{~mm}-\mathrm{ATP}$ (Boehringer disodium salt, buffered to $\mathrm{pH} \mathrm{8.0} \mathrm{with} \mathrm{tris),}$ $15 \mathrm{~mm}$-tris-HCl, $\mathrm{pH} 8.0$, and $0.57-0.79 \mathrm{mg}$. dry wt. of tissue $/ \mathrm{ml}$. The results are the mean values obtained from three experiments. $\mathrm{O}, 10 \mathrm{~mm}-\mathrm{NaCl} ; \square, 50 \mathrm{~mm}-\mathrm{NaCl}$. 
Table 2. Independence of the rate of adenosine triphosphate hydrolysis on the potassium and sodium ion concentrations

The incubations were carried out at $37^{\circ}$ as described in Table 1, with (final concentrations) 5 mM-ATP (Boehringer disodium salt, buffered to $\mathrm{pH} 8.0$ with tris), $15 \mathrm{~mm}$-tris$\mathrm{HCl}, \mathrm{pH} 8.0,5 \mathrm{mM}-\mathrm{MgCl}_{2}$ and $0.50 \mathrm{mg}$. dry wt. of tissue $/ \mathrm{ml}$. The $\mathrm{Na}^{+}$ions added in the ATP solution have been included under the $\mathrm{NaCl}$ column. The mean rate of orthophosphate liberation \pm S.D. was $19 \cdot 5 \pm 0 \cdot 8$. Since this S.D. is less than the $6 \%$ expected in a single experiment, the rates were not significantly different.

\begin{tabular}{|c|c|c|c|}
\hline & of sa & & \multirow{2}{*}{$\begin{array}{c}\text { Rate of } \\
\text { orthophosphate } \\
\text { liberation } \\
\text { ( } \mu \text { moles } / \mathrm{mg} . \text { dry } \\
\text { wt. } / \mathrm{hr} . \text { ) }\end{array}$} \\
\hline $\mathrm{NaCl}$ & $\mathrm{KCl}$ & $\begin{array}{l}\text { Choline } \\
\text { chloride }\end{array}$ & \\
\hline $\begin{array}{r}10 \\
20 \\
40 \\
50 \\
60 \\
80 \\
100\end{array}$ & $\begin{array}{r}10 \\
20 \\
40 \\
50 \\
60 \\
80 \\
100\end{array}$ & $\begin{array}{r}220 \\
200 \\
160 \\
140 \\
120 \\
80 \\
40\end{array}$ & $\begin{array}{l}19.4 \\
18.5 \\
19 \cdot 4 \\
20.4 \\
19.4 \\
20.6 \\
18.9\end{array}$ \\
\hline
\end{tabular}

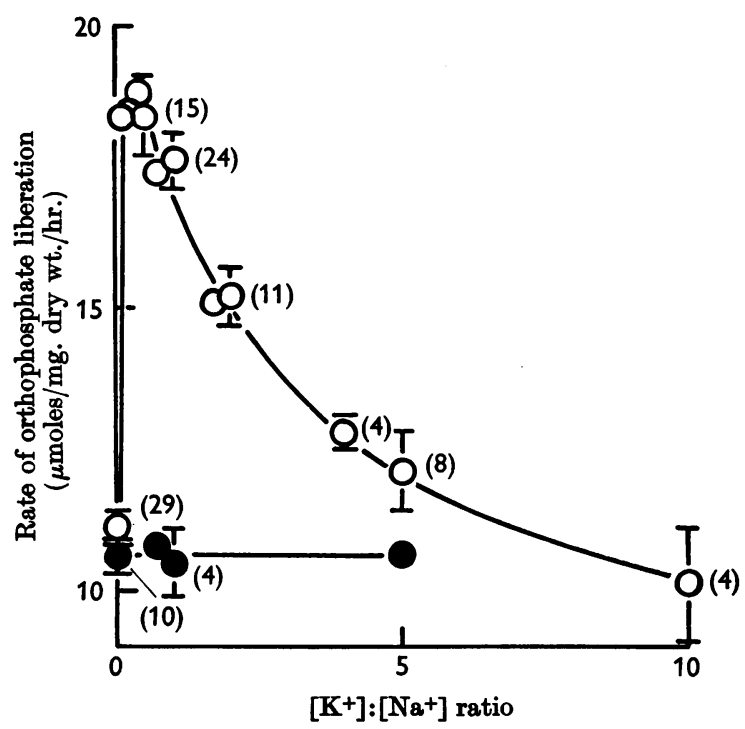

Fig. 8. Dependence of adenosine-triphosphatase activity on the ratio of the $\mathrm{KCl}$ and $\mathrm{NaCl}$ concentrations. The results from ten experiments have been combined, each point being the mean value of at least three observations. The S.F.M. values are shown at suitable intervals on the curve.

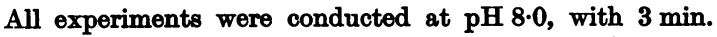
incubations at $37^{\circ}$, with tissue concentrations in the range $0.50-0.92 \mathrm{mg}$. dry wt. $/ \mathrm{ml}$. The $\left[\mathrm{K}^{+}\right]:\left[\mathrm{Na}^{+}\right]$ratio was varied by keeping the concentration of one ion constant and varying that of the other. The media contained (final concentrations) 5 mM-ATP (Sigma or Boehringer disodium salts, buffered to $\mathrm{pH} 8.0$ with tris), $5 \mathrm{~mm}-\mathrm{MgCl}_{2}, 15 \mathrm{mM}$ tris-HCl, pH 8.0, 0-100 mM-KCl, 10-160 mM-Na ${ }^{+}$and choline chloride to maintain iso-osmolarity. $O$, Without ouabain; $O$, with $0.33 \mathrm{~mm}$-ouabain. triphosphatase activity was measured with equal concentrations of $\mathrm{Na}^{+}$and $\mathrm{K}^{+}$ions over a range of concentrations of each ion from 10 to $100 \mathrm{~mm}$ (Table 2). The rate of orthophosphate liberation was, indeed, independent of the $\mathrm{Na}^{+}$ion and $\mathrm{K}^{+}$ion concentrations under these conditions, remaining constant over the whole range of concentrations.

The importance of the ratio of the concentrations of $\mathrm{Na}^{+}$and $\mathrm{K}^{+}$ions became more apparent when the combined results from ten experiments were plotted as the rate of orthophosphate liberation against the $\left[\mathrm{K}^{+}\right]:\left[\mathrm{Na}^{+}\right]$ratio (Fig. 8). In these experiments the concentration of one ion had been kept constant while that of the other was varied, and the range of concentrations covered was 0-100 $\mathrm{mm}$ for $\mathrm{K}^{+}$ion, and $10-160 \mathrm{~mm}$ for $\mathrm{Na}^{+}$ion. The graph shows that, under these conditions, both the occurrence and the magnitude of the stimulation by $\mathrm{Na}^{+}$plus $\mathrm{K}^{+}$ions depended on the $\left[\mathrm{K}^{+}\right]:\left[\mathrm{Na}^{+}\right]$ratio. Moreover, ouabain completely abolished this stimulation, whatever its magnitude. The form of the curve in Fig. 8 suggests that the fall in the rate of ATP hydrolysis might be an exponential function of the $\left[\mathrm{K}^{+}\right]:\left[\mathrm{Na}^{+}\right]$ratio, and the straight line given by the semi-logarithmic plot of rates at $\left[\mathrm{K}^{+}\right]:\left[\mathrm{Na}^{+}\right]$ratios between 1 and 10 indicates that this is so (Fig. 9). Fig. 9 shows also that the rate of hydrolysis was constant and maximal when the $\left[\mathrm{K}^{+}\right]:\left[\mathrm{Na}^{+}\right]$ratio lay between about $0 \cdot 1$ and $1 \cdot 0$.

To investigate further the dependence of the adenosine-triphosphatase activity on the relative concentrations of $\mathrm{Na}^{+}$and $\mathrm{K}^{+}$ions, the rates of

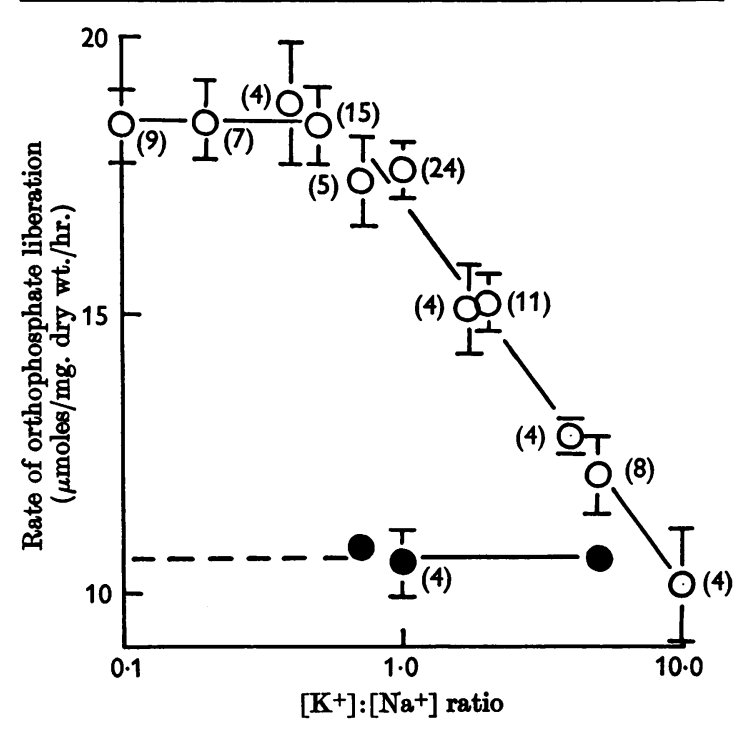

Fig. 9. The exponential fall in adenosine-triphosphatase activity on increasing the $\left[\mathrm{K}^{+}\right]:\left[\mathrm{Na}^{+}\right]$ratio from 1 to 10 . The conditions were as for Fig. 8 . 
ATP hydrolysis were measured when these concentrations were varied by interchanging the ions. Fig. 10 shows that, when the sum of the concentrations of $\mathrm{K}^{+}$and $\mathrm{Na}^{+}$ions was constant at $130 \mathrm{~mm}$, maximal activity occurred with $\mathrm{K}^{+}$ion concentrations in the range $3-65 \mathrm{~mm}$, and $\mathrm{Na}^{+}$ion

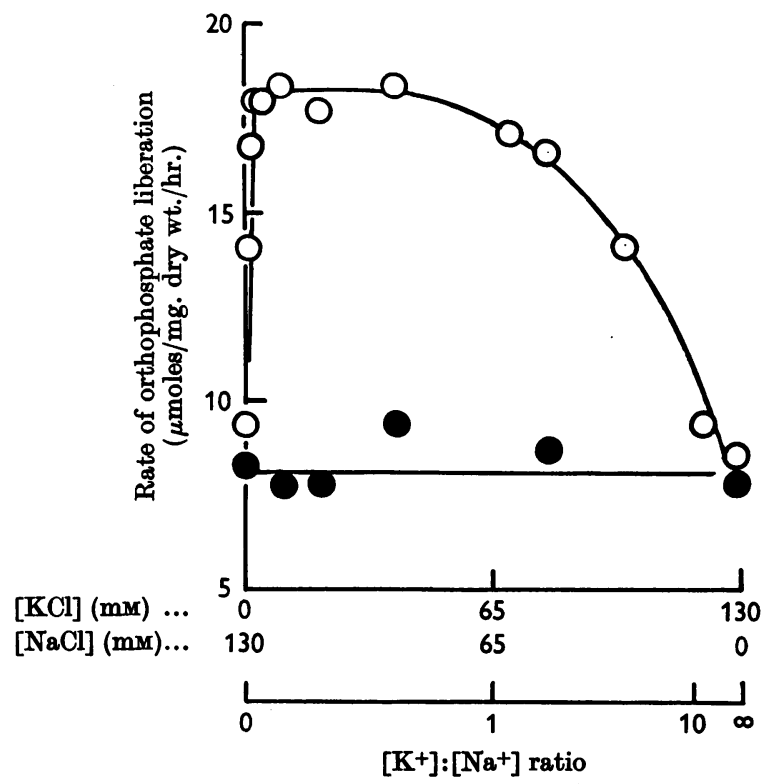

Fig. 10. Effect on adenosine-triphosphatase activity of interchanging the concentrations of $\mathrm{Na}^{+}$and $\mathrm{K}^{+}$ions. Samples of suspension containing (final concentrations) 15 mM-tris-HCl, $\mathrm{pH} 8.0,5 \mathrm{~mm}-\mathrm{MgCl}_{\mathrm{g}}$ and $5 \mathrm{~mm}$-ATP (tris salt, $\mathrm{pH} 8.0$, from the Sigma disodium salt) were incubated for 3 min. at $37^{\circ}$ with the concentrations of $\mathrm{NaCl}$ and $\mathrm{KCl}$ indicated (the $\mathrm{Na}^{+}$ions in the ATP solution have been included). The dry wt. of tissue was $0.52 \mathrm{mg} . / \mathrm{ml}$. $\bigcirc$, Without ouabain; 0 , with $\mathbf{0 . 3 3}$ mM-ouabain. concentrations of 127-65 mM; that is, with $\left[\mathrm{K}^{+}\right]:\left[\mathrm{Na}^{+}\right]$ratios between about 0.02 and 1 . This maximal rate was over $100 \%$ higher than the rates observed with $\left[\mathrm{K}^{+}\right]:\left[\mathrm{Na}^{+}\right]$ratios of either zero or greater than about 12, which were practically unaffected by ouabain. The concentrations of the ions required for half-maximal stimulation of the adenosine-triphosphatase activity under these conditions were about $2 \mathrm{~mm}$ for $\mathrm{K}^{+}$ion and about $25 \mathrm{~mm}$ for $\mathrm{Na}^{+}$ion.

Stimulation by low concentrations of potassium ions. Although the rate of ATP hydrolysis fell when the $\left[\mathrm{K}^{+}\right]:\left[\mathrm{Na}^{+}\right]$ratio was outside of the optimum range of $0.02-1.0$ (Fig. 10), the rising part of the curve corresponding to $\left[\mathrm{K}^{+}\right]:\left[\mathrm{Na}^{+}\right]$ ratios of between 0 and 0.02 was obtained with $\mathrm{K}^{+}$ ion concentrations of 1,2 and $3 \mathrm{~mm}$ while the $\mathrm{Na}^{+}$ ion concentration was almost constant (127$129 \mathrm{~mm}$ ), indicating increasing stimulation due to increasing $\mathrm{K}^{+}$ion concentration. Now, if the adenosine-triphosphatese activity were governed solely by the $\left[\mathrm{K}^{+}\right]:\left[\mathrm{Na}^{+}\right]$ratio, the rate of orthophosphate liberation would fall when the ratio becomes less than 0.02 , owing to an increase in the $\mathrm{Na}^{+}$ion concentration as distinct from a decrease in $\mathrm{K}^{+}$ion concentration. Hence an experiment was designed to find out if a fall in activity occurred on decreasing the $\left[\mathrm{K}^{+}\right]:\left[\mathrm{Na}^{+}\right]$ratio by increasing the $\mathrm{Na}^{+}$ion concentration, keeping the $\mathbf{K}^{+}$ion concentration constant.

The results in Table 3 show conclusively that, with a constant $\mathrm{K}^{+}$ion concentration of $1 \mathrm{~mm}$, raising the $\mathrm{Na}^{+}$ion concentration from 8 to $148 \mathrm{mM}$, corresponding to a fall in the $\left[\mathrm{K}^{+}\right]:\left[\mathrm{Na}^{+}\right]$ratio from $0 \cdot 125$ to $0 \cdot 007$, did not cause a fall in the rate of ATP hydrolysis. The results were essentially the same whether sucrose or choline was used to maintain iso-osmolarity, and they show that the fall in adenosine-triphosphatase activity seen on

Table 3. Dependence of adenosine-triphosphatase activity on the potassium ion concentration in the presence of high concentrations of sodium ion

The rates of orthophosphate liberation from ATP were measured at $37^{\circ}$, as described in Table 1 , in tissue suspensions containing (final concentrations) $4 \mathrm{~mm}$-ATP (Sigma disodium salt, buffered to pH 8.0 with tris), $4 \mathrm{mM}-\mathrm{MgCl}_{2}, 15 \mathrm{~mm}$-tris-HCl, $\mathrm{pH} 8 \cdot 0$, and $0.28 \mathrm{mg}$. dry wt. of tissue $/ \mathrm{ml}$.

Concn. of
$\mathrm{K}+$ ion

(mM)

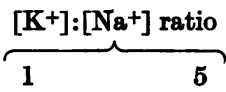

Medium ...

$\mathrm{Na}+$ ion

(mM)

$\begin{array}{rll}8 & 0.125 & 0.625 \\ 48 & 0.021 & 0.104 \\ 98 & 0.010 & 0.051 \\ 148 & 0.007 & 0.034\end{array}$

Rate of orthophosphate liberation ( $\mu$ moles/mg. dry wt./hr.)

\begin{tabular}{|c|c|c|c|c|}
\hline & & & & $\begin{array}{l}\text { Percentage increase in } \\
\text { rate on increasing } \mathrm{K}^{+} \\
\text {concn. from } 1 \text { to } 5 \mathrm{~mm}\end{array}$ \\
\hline Choline & Sucrose & Choline & Sucrose & Choline \\
\hline
\end{tabular}

$\begin{array}{ll}14 \cdot 2 & 14 \cdot 4 \\ 15 \cdot 7 & 17 \cdot 1 \\ 15 \cdot 7 & 17 \cdot 1 \\ 16 \cdot 5 & 15 \cdot 2\end{array}$

$13 \cdot 6$
$18 \cdot 8$
$19 \cdot 4$
$18 \cdot 6$

+1
+24
+22


reducing the $\left[\mathrm{K}^{+}\right]:\left[\mathrm{Na}^{+}\right]$ratio below 0.02 (Fig. 10) was indeed due to the change in the $\mathrm{K}^{+}$ion concentration, because a similar reduction of the ratio due to a change in the $\mathrm{Na}^{+}$ion concentration did not cause a fall. The control of adenosine-triphosphatase activity by the $\mathrm{K}^{+}$ion concentration when the $\mathrm{Na}^{+}$ion concentration was high is illustrated by the increased activity observed on raising the $\mathrm{K}^{+}$ion concentration from 1 to $5 \mathrm{~mm}$ with various concentrations of $\mathrm{Na}^{+}$ions (Table 3).

Thus it appears that the magnitude of the stimulation of the adenosine-triphosphatase activity by both $\mathrm{Na}^{+}$and $\mathrm{K}^{+}$ions depends partially on the concentrations of these ions and partially on the ratio of their concentrations. An increase in the $\mathrm{K}^{+}$ion concentration can cause either a rise $\left(\left[\mathrm{K}^{+}\right]:\left[\mathrm{Na}^{+}\right]\right.$ratio less than 1$)$ or a fall $\left(\left[\mathrm{K}^{+}\right]:\left[\mathrm{Na}^{+}\right]\right.$ ratio greater than 1) in the rate of ATP hydrolysis, depending on the $\mathrm{Na}^{+}$ion concentration; but an increase in the $\mathrm{Na}^{+}$ion concentration can cause only a rise in the rate, never a fall, and the extent of the rise depends on the $\mathrm{K}^{+}$ion concentration. If the $\left[\mathrm{K}^{+}\right]:\left[\mathrm{Na}^{+}\right]$ratio exceeds about 10 , no stimulation of the adenosine-triphosphatase activity is observed.

\section{DISCUSSION}

We have used the term 'adenosine triphosphatase' in the customary manner (Kielley, 1961), without implying that the observed hydrolysis of ATP is the result of the action of only one enzyme. A combination of two enzymes could clearly produce the same effect, as is illustrated in the following examples:

(a) Hexokinase and a phosphatase:

ATP + glucose $\rightarrow$ glucose 6-phosphate + ADP

Glucose 6-phosphate $\rightarrow$ glucose + orthophosphate

(b) Diglyceride kinase and phosphatidic acid phosphatase:

ATP + diglyceride $\rightarrow$ phosphatidic acid + ADP

Phosphatidic acid $\rightarrow$ diglyceride + orthophosphate

(c) Phosphoprotein kinase and phosphoprotein phosphatase:

$\mathrm{ATP}+$ protein $\rightarrow$ phosphoprotein $+\mathrm{ADP}$

Phosphoprotein $\rightarrow$ protein + orthophosphate

Although these alternatives to a single enzyme acting directly on ATP have not yet been eliminated, the term 'adenosine triphosphatase' has been used in this paper as it provides a convenient description for the catalysis of the overall reaction which was measured, namely:

$$
\text { ATP } \rightarrow \text { ADP + orthophosphate. }
$$

The results indicate that $\mathrm{Mg}^{2+}$ ions are obligatory for enzymic activity, and that synergic stimulation by $\mathrm{Na}^{+}$and $\mathrm{K}^{+}$ions depends on the ratio of the concentrations of these ions and is inhibited by ouabain. Scheme 1 summarizes our observations and provides a basis for further investigations. Good evidence exists for the formation by $\mathrm{Mg}^{2+}$ ions, ATP and adenosine triphosphatases in general, of complexes which break down to give ADP and orthophosphate. The Scheme

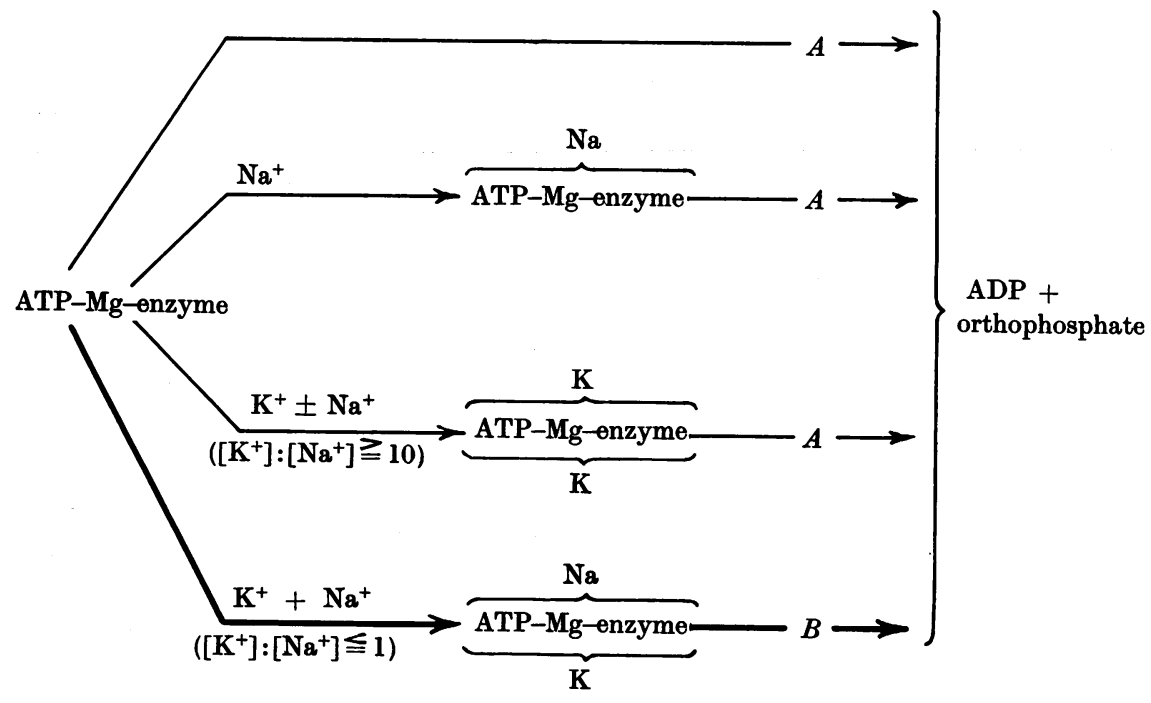

Scheme 1. Probable intermediate complexes in the synergic activation by $\mathrm{Na}^{+}$and $\mathrm{K}^{+}$ions of ATP hydrolysis. Rate $B$ is decreased by ouabain to rate $A$, which is not affected by ouabain. 
shows that the addition of $\mathrm{Na}^{+}$or $\mathrm{K}^{+}$ions alone does not cause an increase in the rate of ATP hydrolyses above that observed with $\mathrm{Mg}^{2+}$ ions alone (rate $A$ ), although it is reasonable to assume that the alkali metal ions form some attachment with the enzyme complex. In the presence of $\mathrm{Na}^{+}$ and $\mathrm{K}^{+}$ions together, a higher rate of hydrolysis (rate $B$ ) is found which is decreased to rate $A$ by ouabain. The higher rate, $B$, must be due to the reaction proceeding through an intermediate complex, involving $\mathrm{Na}^{+}$and $\mathrm{K}^{+}$ions, which causes a faster reaction than is found with complexes involving $\mathrm{Na}^{+}$or $\mathrm{K}^{+}$ions alone.

Our findings do not exclude the possibility that the ATP hydrolysis observed in the presence of $\mathrm{Mg}^{2+}$ ions alone, $\mathrm{Na}^{+}$plus $\mathrm{Mg}^{2+}$ ions, or $\mathrm{K}^{+}$plus $\mathrm{Mg}^{2+}$ ions, might be due to an adenosine triphosphatase which is not activated synergically in the presence of all three cations. If this is the situation, the increase above the basal ouabain-insensitive rate observed on adding $\mathrm{Na}^{+}$and $\mathrm{K}^{+}$ions together would be due to the activation of a separate enzyme, implying that there are then two pathways for ATP hydrolysis, compared with only one in the presence of $\mathrm{Mg}^{2+}$ ions alone, $\mathrm{Mg}^{2+}$ plus $\mathrm{Na}^{+}$ions, or $\mathrm{Mg}^{2+}$ plus $\mathrm{K}^{+}$ions. Some evidence that two such adenosine triphosphatases may be present in submicroscopic particles from kidney homogenate is provided by the enhancement of the proportion of adenosine-triphosphatase activity sensitive to $\mathrm{Na}^{+}$ and $\mathrm{K}^{+}$ions by different fractionation procedures (Skou, 1962).

In the presence of optimum $\mathrm{K}^{+}$ion concentrations, maximal stimulation is given when the ratio $\left[\mathrm{K}^{+}\right]:\left[\mathrm{Na}^{+}\right]$is less than 1 . A gradual fall in adenosine-triphosphatase activity occurred as the ratio was increased from 1 to 10 and no stimulation occurred with a ratio greater than about 10. It seems reasonable to suppose that maximal activity is given with an intermediate

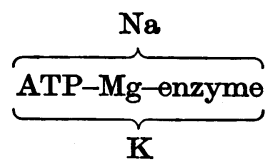

involving both $\mathrm{Na}^{+}$and $\mathrm{K}^{+}$ions, whereas with excess of $\mathrm{K}^{+}$ions the less-active complex

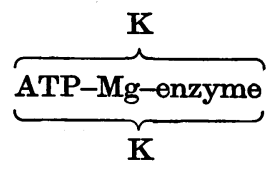

gives the low ouabain-insensitive rate (Scheme 1). With $\left[\mathrm{K}^{+}\right]:\left[\mathrm{Na}^{+}\right]$ratios between 1 and 10 , a mixture of these two complexes would account for the partial stimulations observed. Displacement of $\mathrm{Na}^{+}$ions by excess of $\mathrm{K}^{+}$ions from some enzymic active site is the simplest explanation of these findings. In contrast with the fall in activity with excess of $\mathrm{K}^{+}$ions, the addition of excess of $\mathrm{Na}^{+}$ions had no effect, suggesting that $\mathrm{K}^{+}$ions are not displaced by $\mathrm{Na}^{+}$ions from their site of activation.

The prevention by ouabain of the $\mathrm{Na}^{+}$ion-plus$\mathrm{K}^{+}$ion stimulation could be caused by inhibition either of the formation of the intermediate complex involving both $\mathrm{Na}^{+}$and $\mathrm{K}^{+}$ions or of the breakdown of this complex. These possibilities have not been tested directly, but Skou (1960) has concluded from indirect evidence that, with the crab-nerve enzyme, ouabain probably interferes with the binding of $\mathrm{Na}^{+}$and $\mathrm{K}^{+}$ions to the enzymesubstrate complex. Further, Dunham \& Glynn (1961) showed that the inhibition by low concentrations of ouabain of the adenosine-triphosphatase activity of fragmented erythrocyte membranes could be overcome by raising the $\mathrm{K}^{+}$ion concentration, again suggesting that ouabain interferes with the formation of an intermediate involving $\mathrm{K}^{+}$ ions.

An important aspect of this and similar investigations is the exact morphological origin of the enzyme preparation employed. The nuclear fraction from kidney-cortex homogenate was a crude preparation, far from homogeneous, which probably contained some whole cells, mitochondria and a few erythrocytes, as well as nuclei and membrane material (Stirpe \& Aldridge, 1961). Nevertheless, the activity observed is probably due to cell membranes because Emmelot \& Bos (1962) have also described a $\mathrm{Na}^{+}$ion-plus- $\mathrm{K}^{+}$ion-activated adenosine triphosphatase in cell membranes from rat-liver homogenates which were derived from a nuclear fraction. They employed a slight modification of Neville's (1960) procedure which yields a pure-membrane preparation. Although a comparison of the present findings with those obtained with various pure-membrane preparations indicates that we have been measuring a membrane adenosinetriphosphatase activity, further work is needed to characterize and purify the kidney preparation.

Another important consideration concerns the extrapolation of results found with fragmented cells and tissues to mechanisms of active ion transport in intact cells. Even if the adenosine triphosphatase studied is indeed located in membrane material, care must be taken in interpreting the results because of the disrupted nature of the preparation. In the intact cell the two sides of the membrane are distinct, and are exposed to different concentrations of $\mathrm{Na}^{+}$and $\mathrm{K}^{+}$ions, but in suspensions of fragmented cells both sides of the membranes are simultaneously exposed to the same concentrations of activators or inhibitors, so that the effects observed might well bear little relation to those which would occur in the intact cell. In 
addition to normal chemical steric effects involved in ATP hydrolysis, $\mathrm{Na}^{+}$and $\mathrm{K}^{+}$ions may activate from opposite sides of the membrane in kidney as they do in erythrocyte stroma, in which $\mathrm{Na}^{+}$ions activate from inside and $\mathrm{K}^{+}$ions from outside (Glynn, 1962; Whittam, 1962a). The adenosine triphosphatase studied in fragmented membranes, on the other hand, is not subject to the spatial asymmetry characteristic of membranes in intact cells. Moreover, further indications of the dependence of adenosine-triphosphatase characteristics on structural integrity are provided by the increasing dependence of mitochondrial adenosine triphosphatases on the presence of added $\mathrm{Mg}^{2+}$ ions as mitochondria are fragmented (Kielley, 1961; Kielley \& Kielley, 1953; Lardy \& Wellman, 1953; Bronk \& Kielley, 1957; Cooper \& Lehninger, 1957), and the similar variability of the action of $\mathrm{Ca}^{2+}$ ions on these enzymes (Kielley, 1961). These considerations must be borne in mind when the implications of the various activations and inhibitions of ATP hydrolysis noted above are discussed.

If a $\mathrm{Na}^{+}$ion-plus- $\mathrm{K}^{+}$ion-activated adenosine triphosphatase is indeed associated with movements of $\mathrm{Na}^{+}$and $\mathrm{K}^{+}$ions against concentration gradients, the question arises whether these movements are an integral part of the enzymic reaction. Directional movements of $\mathrm{Na}^{+}$and $\mathrm{K}^{+}$ions might accompany an enzymic reaction in a way comparable to the usual steric changes involved in many chemical reactions. Such directional movements of $\mathrm{Na}^{+}$and $\mathrm{K}^{+}$ions associated with the hydrolysis of ATP would be compatible with the stimulation of hydrolysis by these ions at the sides of the membrane from which they are transported. Further study of the membrane-catalysed hydrolysis of ATP from a more chemical viewpoint should throw light on the processes of hydrolysis and ion movements.

In spite of the qualifications discussed above, the similarity between active transport and the synergic activation of the adenosine triphosphatase by $\mathrm{Na}^{+}$and $\mathrm{K}^{+}$ions, and the inhibition of both processes by ouabain, is striking. The concept of an intimate linkage between ATP hydrolysis and active cation transport suggested by these results is supported by the further parallelism of the effects of $\mathrm{Na}^{+}$ions and ouabain on a part of the respiration in kidney and brain cortex (Whittam, $1961 b$, 1962b). A ouabain-sensitive adenosine triphosphatase therefore appears to be involved in the regulation of both oxygen consumption and active cation transport.

\section{SUMMARY}

1. The rate of hydrolysis of ATP to ADP, catalysed by a nuclear fraction from rabbit-kidneycortex homogenate, has been measured under a variety of conditions designed to find out if the reaction is affected by $\mathrm{Na}^{+}$and $\mathrm{K}^{+}$ions, and by ouabain, which are known to affect active ion movements in the intact tissue.

2. The optimum $\mathrm{pH}$ within the range $6 \cdot 5-9 \cdot 1$ for the adenosine-triphosphatase activity in the presence of $110 \mathrm{~mm}-\mathrm{Na}^{+}$ion, $20 \mathrm{~mm}-\mathrm{K}^{+}$ion and equimolar concentrations (4 mM) of ATP and magnesium chloride was between $7 \cdot 8$ and $8 \cdot 1$. When ouabain $(0.33 \mathrm{~mm})$ was also present, the lower activity was much less dependent on $\mathrm{pH}$ in this range.

3. Adenosine-triphosphatase activity at $\mathrm{pH} 8 \cdot 0$ was negligible in the absence of $\mathrm{Mg}^{2+}$ ions and maximal with $\left[\mathrm{Mg}^{2+}\right]$ : [ATP] ratios of $0 \cdot 5-1 \cdot 5$.

4. The addition of $\mathrm{Na}^{+}$and $\mathrm{K}^{+}$ions together, but not separately, stimulated the rate of ATP hydrolysis, the magnitude of the stimulation depending partly on the $\mathrm{Na}^{+}$and $\mathrm{K}^{+}$ion concentrations and partly on the ratio of these concentrations. With optimum or excess of $\mathrm{Na}^{+}$ions present, raising the $\mathrm{K}^{+}$ion concentration first increased the activity $\left(\left[\mathrm{K}^{+}\right]:\left[\mathrm{Na}^{+}\right]\right.$ratio less than 1$)$, but further increase in the $\mathrm{K}^{+}$ion concentration $\left(\left[\mathrm{K}^{+}\right]:\left[\mathrm{Na}^{+}\right]\right.$ ratio greater than 1) caused a fall in activity. With optimum or excess of $\mathrm{K}^{+}$ions present, the gradual addition of $\mathrm{Na}^{+}$ions caused an increase in rate, which reached a maximum when the $\left[\mathrm{K}^{+}\right]:\left[\mathrm{Na}^{+}\right]$ ratio was less than about 1 and remained constant during further addition of $\mathrm{Na}^{+}$ions. When the $\left[\mathrm{K}^{+}\right]:\left[\mathrm{Na}^{+}\right]$ratio exceeded about 10 , no stimulation of the adenosine-triphosphatase activity was observed.

5. The concentrations of ions required for halfmaximal stimulation of the rate of ATP hydrolysis were about $2 \mathrm{mM}-\mathrm{K}^{+}$ion and about $25 \mathrm{mM}-\mathrm{Na}^{+}$ion when the sum of the concentrations of these ions was constant at $130 \mathrm{~mm}$.

6. Ouabain (0.1 mM) completely abolished the stimulation caused by $\mathrm{Na}^{+}$and $\mathrm{K}^{+}$ions but had no effect on the activity due to $\mathbf{M g}^{\mathbf{2}+}$ ions alone. About $20 \mu \mathrm{M}$-ouabain caused half-maximal inhibition of the $\mathrm{Na}^{+}$ion-plus- $\mathrm{K}^{+}$ion-dependent adenosinetriphosphatase activity. The inhibition by ouabain was not competitive with respect to ATP.

7. Measurements of the $K_{m}$ gave values in the range $0.4-0.7 \mathrm{~mm}-\mathrm{ATP}$ for the hydrolysis depending on the presence of $\mathrm{Mg}^{2+}, \mathrm{Na}^{+}$and $\mathrm{K}^{+}$ions, and 0.6-1.4 mM-ATP for the ouabain-sensitive part of the hydrolysis.

8. In spite of qualifications arising from the heterogeneous nature of the preparation, and from the lack of membrane structural integrity and of directional ion movements in a suspension, the results suggest that a kidney adenosine triphosphatase is stimulated and inhibited in a similar way to active transport and a part of cellular oxygen consumption. 
This work was supported by grants from the U.S. Public Health Service and the Rockefeller Foundation, and was done during the tenure by one of us (K.P.W.) of a grant from the Department of Scientific and Industrial Research.

\section{REFERENCES}

Aldridge, W. N. (1962). Biochem. J. 83, 527.

Amoore, J. E., Parsons, D. S. \& Werkheiser, W. C. (1958). Biochem. J. 69, 236.

Bartlett, G. R. (1959). J. biol. Chem. 234, 466.

Bock, R. M., Nan-Sing Ling, Morell, S. A. \& Lipton, S. H. (1956). Arch. Biochem. Biophys. 62, 253.

Bonting, S. L., Simon, K. A. \& Hawkins, N. M. (1961). Arch. Biochem. Biophys. 95, 416.

Bronk, J. M. \& Kielley, W. W. (1957). Biochim. biophys. Acta, 24, 440.

Cooper, C. \& Lehninger, A. L. (1957). J. biol. Chem. 224, 547.

Deul, D. H. \& MoIlwain, H. (1961). J. Neurochem. 8, 246.

Dunham, E. T. \& Glynn, I. M. (1961). J. Physiol. 156, 274.

Emmelot, P. \& Bos, C. J. (1962). Biochim. biophys. Acta, 58, 375 .

Fiske, C. H. \& Subbarow, Y. (1925). J. biol. Chem. 66, 375. Glynn, I. M. (1962). J. Physiol. 160, 18 P.

Hess, H. \& Pope, A. (1957). Fed. Proc. 16, 196.

Järnefelt, J. (1961). Biochim. biophys. Acta, 48, 104.

Kielley, W. W. (1961). In The Enzymes, vol. 5, part B, pp. 149-157. Ed. by Boyer, P. D., Lardy, H. \& Myrbäck, K. New York and London: Academic Press Inc.
Kielley, W. W. \& Kielley, R. K. (1953). J. biol. Chem. 200, 213.

Krebs, H. A. \& Hems, R. (1953). Biochim. biophys. Acta, $12,172$.

Lardy, H. A. \& Wellman, H. (1953). J. biol. Chem. 201, 1357.

Layne, E. (1957). In Methods in Enzymology, vol. 3, p. 450. Ed. by Colowick, S. P. \& Kaplan, N. O. New York: Academic Press Inc.

Mudge, G. H. (1951). Amer. J. Physiol. 167, 206.

Neville, P. M. (1960). J. biophys. biochem. Cytol. 8, 413.

Perry, S. V. \& Grey, T. C. (1956). Biochem. J. 64, 184.

Post, R. L., Merritt, C. R., Kinsolving, C. R. \& Albright, C. D. (1960). J. biol. Chem. 235, 1796.

Robinson, H. W. \& Hogden, C. G. (1940). J. biol. Chem. 135, 709 .

Skou, J. C. (1957). Biochim. biophys. Acta, 22, 394.

Skou, J. C. (1960). Biochim. biophys. Acta, 42, 6.

Skou, J. C. (1962). Biochim. biophys. Acta, 58, 314.

Stirpe, F. \& Aldridge, W. N. (1961). Biochem. J. 80, 481.

Swanson, M. A. (1951). J. biol. Chem. 191, 577.

Tosteson, D. C., Moulton, R. H. \& Blaustein, M. P. (1960). Fed. Proc. 19, 128.

Whittam, R. (1961a). Rep. Progr. Chem. 57, 379.

Whittam, R. (1961 b). Nature, Lond., 191, 603.

Whittam, R. (1962a). Biochem. J. 84, 110.

Whittam, R. (1962b). Biochem. J. 82, 205.

Whittam, R. \& Davies, R. E. (1954). Biochem. J. 56, 445.

Whittam, R. \& Wheeler, K. P. (1961). Biochim. biophys. Acta, 51, 622.

\title{
A Study of the 'Reactive' Sulphydryl Groups of Adenosine 5 '-triphosphate-Creatine Phosphotransferase
}

\author{
By D. C. WATTS* AND B. R. RABIN \\ Department of Biochemistry, University College London, Gower Street, London, W.C. 1
}

(Received 17 April 1962)

Creatine kinase (adenosine $5^{\prime}$-triphosphatecreatine phosphotransferase, EC 2.7.3.2) catalyses the reaction shown in eqn. (1):

$\mathrm{ATP}^{4-}+$ creatine $\rightleftharpoons \mathrm{ADP}^{3-}+$ phosphocreatine $e^{2-}+\mathrm{H}^{+}$

with $\mathrm{pH}$ optima for the forward reaction (formation of ADP) and reverse reaction of approximately 9.0 and 7.0 respectively (Kuby, Noda \& Lardy, $1954 b$ ). The enzyme has two 'reactive' sulphydryl groups (Benesch, Lardy \& Benesch, 1955), and the reaction of these with a variety of reagents inhibits the phosphate-transfer reaction (Mahowald \& Kuby, 1960; Watts, Rabin \& Crook, 1961).

* Beit Memorial Fellow.
Most samples of the enzyme, as prepared from individual rabbits, have two active sites, and a single sulphydryl group is associated with each. One sample of the enzyme, with only one active site, has been prepared in this Laboratory. In this preparation only one of the 'reactive' sulphydryl groups is concerned with the catalytic activity, and blocking of the other is without significant effect on the catalytic function (Watts, Rabin \& Crook, 1962). Thus the existence of a single 'active' sulphydryl group associated with each catalytic site of the enzyme is a tenable hypothesis. Its function in the catalytic process has proved more contentious (Dixon, 1949; Padieu \& Mommaerts, 1960; Ennor \& Morrison, 1958; Rabin \& Watts, 1960). The 